DOI: $10.19195 / 0524-4544.327 .14$

\author{
EDVINS DANOVSKIS \\ ORCID: 0000-0001-7848-7945 \\ University of Latvia \\ edvins.danovskis@lu.lv
}

\title{
Basic concepts and current developments of Latvian administrative law
}

\begin{abstract}
The article outlines some basic elements of Latvian administrative law, namely the civil service system, state liability law and administrative offence law. The Latvian civil service system is characterized as a decentralized position model, and concepts of "decentralization" and "position" model are briefly described. In the context of state liability law a recent development of the introduction of the concept of "non-material harm" is outlined, explaining why Latvian administrative law has abandoned the concept of "moral harm" used previously. Regarding administrative offence law the article describes the most significant changes to be introduced into legislation in 2018.
\end{abstract}

Keywords: Latvian administrative law, civil service, state liability, administrative offence law.

\section{Introduction}

Administrative law has traditionally been considered as a very "national" branch of law, regulating a vast number of different fields in the activity of public administration. The development of administrative law is very dependent on many historical aspects and local peculiarities. However, there are fields of administrative law that have a magnificent and unused potential for comparative analysis. Accounts and analysis of local experiences on particular issues of administrative law, such as the scope of judicial review or enforcement of the principle of loyalty in the civil service, or on conditions precluding liability for administrative offences can provide valuable data for further research and discoveries of broader interconnections of administrative law. The scope of comparative analysis often depends upon language barriers and not the population or land area of a state. The same legal problems of administrative law arise both in large and small states. Sometimes 
these are "small" states that can demonstrate novel approaches and valuable data for further development of legal thinking. It is this spirit in which this article, dedicated to the 100th anniversary of the independence of the Baltic states is written. The Baltic states and Poland had to "restart" their legal systems twice: in 1918 and after the collapse of their communist governments in 1989-1990. Although each state had a goal to implement the rule of law in the activities of public administration, the paths and solutions to achieve this goal have been quite different.

This article is intended to give a general insight into the basic features of Latvian administrative law in the hope that some information contained in this article might be useful for those who study administrative law from a comparative perspective. The areas covered in this article are the civil service, state liability and administrative offence law - although these areas of law are not interrelated, they may give an insight into the level of development and some solutions to problems familiar in many legal systems. A broader account of Latvian administrative law is published in the book The Law of the Baltic States. ${ }^{1}$

\section{Latvian administrative law in the European context}

The European legal scholarship has produced several fundamental works in the last decade which might inspire further development of comparative administrative law. A notable example is the Handbuch Ius Publicum Europaeum ${ }^{2}$ in six volumes - the result of a scientific project with the aim highlighting similarities and differences of administrative law in various European legal systems. This work was continued in the series of The Max Planck Handbooks in European Public Law ${ }^{3}$ in which professor Michel Fromont outlined the three most important types of administrative law in Europe: the French, the German and the British type. ${ }^{4}$ As has been concluded previously, "the basic structure, concepts and methodology of application of Latvian administrative law is similar to other German-based administrative law systems. This is characterized in several features of Latvian administrative law. First, the system of sources of law is similar to the German system. There are basic sources (normative enactments [the Constitution, laws, regulations and bylaws], general principles of law and customary

1 J. Briede, E. Danovskis, "Administrative law and procedure", [in:] The Law of the Baltic States, eds. T. Kerikmäe et al., Cham 2017, pp. 204-217.

2 Handbuch Ius Publicum Europaeum, vols. 1-6, Heidelberg 2007-2016.

3 A. von Bogdandy, P.M. Huber, S. Cassese, eds., The Administrative State, The Max Planck Handbooks in European Public Law, vol. 1, Oxford 2017.

4 M. Fromont, "A typology of administrative law in Europe", [in:] The Administrative State, pp. 579-600. 
law) and secondary sources of law (jurisprudence, legal thesis in court rulings, etc.). Second, some of the basic concepts of administrative law are clearly derived from German administrative law. This can be seen in administrative procedure, where a German concept such as the Administrative Act (Verwaltungsakt) is introduced in Latvian Administrative Procedure Law. Third, it is well known that several parts of Latvian Administrative Procedure Law (general provisions and administrative procedure within institutions) were drafted under the influence of German Administrative Procedure Law (Verwaltungsverfahrensgesetz) and Portuguese Administrative Procedure Law, which is also influenced by German Law. Fourth, the doctrinal understanding of the structure of administrative law is also rather similar to Germany. However, there are also many differences and national peculiarities". 5 The inclination toward a German system was a deliberate choice made by those who at the end of the 1990s drafted Administrative Procedure Law. ${ }^{6}$ It was mainly due to practical considerations: in order to successfully implement the principle of the rule of law, it was easier to look for a successful and well-known example of administrative legal order in a particular European country rather than experiment with compilations or to search for other original ideas.

Latvian administrative law flourished both in the praxis and in the legal scholarship only after 2004, when Administrative Procedure Law came into force and administrative courts were established. In the Soviet period and in the first years after regaining independence administrative law was a "boring" subject in the university curriculum, because it concentrated mainly on the inner organization of the government. Since administrative courts were entitled to effectively review legality of the government acts against private persons, administrative law has become a well-developed area of law.

In Latvia administrative courts have gained trustworthiness and popularity from litigants. According to Article 184 of Administrative Procedure Law, administrative courts can resolve disputes arising from administrative acts, physical acts and contracts of public law. The definition of an administrative act is provided in Article 1, Part Three of Administrative Procedure Law and contains five mandatory elements: (1) only decisions affecting persons outside the government are administrative acts (with the exception of decisions determining status ${ }^{7}$ or basic human rights of public officials, students, prisoners, etc.), (2) the act is issued by an authority exercising functions of executive power ${ }^{8}$ (this includes even private persons who perform government tasks, for instance, mandatory auto safety cer-

5 J. Briede, E. Danovskis, op. cit., p. 204.

6 Administrative Procedure Law, adopted on 25.10.2001, English translation available at: https://likumi.lv/ta/en/en/id/55567-administrative-procedure-law (accessed: 1.07.2018).

${ }^{7}$ For instance, decisions on establishment or termination or civil service relationships or enrollment of a person at university.

8 Even the parliament or courts in some instances execute executive functions, for instance in cases regarding access to documents (freedom of information). 
tificates in Latvia are issued by several limited liability companies), (3) the act is issued in the area of public law (decisions regarding private legal relationships of the government normally are not administrative acts $\left.{ }^{9}\right)$, (4) the act is issued toward individual persons (normative enactments, including local government bylaws are not administrative acts), (5) the act creates legal consequences (creates, terminates or modifies legal relationships) of a final nature (procedural decisions, for instance, regarding renewal of procedural terms, are not administrative acts). For the purposes of legal certainty the same provision clearly states that administrative acts are not political decisions (those which do not need legal grounds, for instance decision of the prime minister to dismiss a minister),${ }^{10}$ court judgments, decisions made in criminal proceedings or proceedings in administrative offence cases. These elements of administrative law largely illustrate which government activities may come under the legal scrutiny of the courts and those which fall out of legal control.

Physical action corresponds to all elements of an administrative act, except that physical action is not a decision and creates physical, not legal consequences. Physical action is, for instance, bodily harm done by the police while suppressing a riot. Most applications on review of the legality of physical action come from prisoners regarding possible violations of human rights in prison facilities. Since 2004 a vast case law has been produced on the competence issues, that is, whether the contested decision, action or contract corresponds to the concept of administrative act, physical act or contract of public law. ${ }^{11}$

Administrative courts are entitled to review the legality of the contested administrative act, including review of whether the administration has properly used its discretion. Administrative courts are entitled to annul the administrative act, declare it illegal (if no other remedy against it exists) or to satisfy a claim to issue a beneficial administrative act. However, in the case of satisfying a claim to issue a beneficial administrative act (for instance, building permission) the court is not entitled to determine the contents of such an act, if the legal provisions entitles the administration with discretion.

This short insight into the judicial review of administrative cases seems rather similar to other German-based administrative systems. Today, Latvian administrative procedure is stable and well developed both in legal provisions and case law,

${ }^{9}$ However, there are some instances when before establishment of private legal relationships an administrative act is issued. A notable example is public procurement procedure.

10 However, even some acts adopted by the parliament regarding impeachment of public officials can be administrative acts, if such a decision can be adopted on legal grounds only. For instance, administrative courts have examined the legality of a decision of the parliament to dismiss from office the chairman of the National Electronic Mass Media Council. See Judgment of the Supreme Court of 22.09.2017 in case no. 767/2017, available at: https://manas.tiesas.lv/eTiesasMvc/ nolemumi/pdf/328468.pdf (accessed: 1.07.2018).

11 See also J. Briede, E. Danovskis, op. cit., pp. 210-211, 214-215. 
cherishing the principle of rule of law in the relationships between administration and individuals. If 20 years ago such principles as proportionality, prohibition of arbitrariness, fair procedure and rule of law were almost unheard of in Latvian administration, then today adoption and implementation of Administrative Procedure Law is widely seen as a "success story". Although the "core" elements of administrative law have been well cemented, there are areas of administrative law which seek consistent attention from both scholarship and the legislator. These areas include the civil service system, administrative offence law and state liability law.

\section{The civil service system and its development in Latvia}

Latvia has had to establish its civil service system twice: after proclamation of the state in 1918 and after regaining independence in 1990. On both occasions there were two challenges: to draft legal provisions on the civil service and to recruit reliable civil servants. ${ }^{12}$ After regaining independence it was of crucial importance to ensure that loyal and qualified persons are recruited in civil service positions. The term "civil service" was a rather new concept, since in the period of Soviet occupation there did not exist particular legal regulations for those who were employed in state institutions - provisions of the Labor Code were applicable to all employees irrespective of institution or position. The first law of the civil service was adopted in 1994, but only six years later it was replaced by a new Civil Service Law. ${ }^{13}$

The Civil Service Law regulates only one part of persons who are employed in public administration. In general there are three categories of employment legal relationships in public administration. The first are so-called "position" relationships - classic examples of persons employed in position relationships are members of the parliament, the president, members of the Cabinet of Ministers, members of the municipality councils, judges and other persons elected in the office on the basis of a purely political decision. These legal relationships are characterized by the fact that the only legal decision establishing the status and duties of the respective person is the political decision to elect them in the office -

12 On establishment of the civil service system after proclamation of Latvia see: E. Danovskis, "Establishment of the civil service in Latvia after the proclamation of the state (1918-1920)", Journal of the University of Latvia "Law" 2014, no. 7, at: https://www.journaloftheuniversityoflatvialaw.lu.lv/fileadmin/user_upload/lu_portal/projekti/journaloftheuniversityoflatvialaw/No7/8. Edvins_Danovskis.pdf (accessed: 1.07.2018).

${ }^{13}$ State Civil Service Law, adopted on 7.09.2000, English translation available at: https:// likumi.lv/ta/en/en/id/10944-state-civil-service-law (accessed: 1.07.2018). 
there are no other legal documents of an individual nature like a contract or job description. Competences and duties of such persons are regulated only by the law.

The largest part of those employed in public administration are employees persons employed within ordinary private legal relationships regulated by Labor Law. ${ }^{14}$ All persons employed in the local municipalities (except members of municipality councils) are employees, even police officers of the municipal police. Employees are also employed in other public institutions, like the Bank of Latvia, Financial and Capital Market Commission, state universities, etc. Disputes arising out of these legal relationships are reviewed by the ordinary courts in accordance with Civil Procedure Law. ${ }^{15}$

The third type of employment legal relationships is public service relationships. The concept of "public service" in Latvia refers to public legal relationships in various State institutions where the master (the State) has broad rights to determine the duties of the servants, including unilateral transfer to other positions. These relationships are established and terminated with an administrative act. There are four major groups of public service employees: (1) civil servants, (2) police officers, firefighters, border guards and officers employed in the Custody Authority, (3) military officers and (4) prosecutors. ${ }^{16}$ This list is not exhaustive, because there are "closed" public service systems for particular institutions, like state security institutions or the Corruption Prevention and Combating Bureau.

The definition of a civil servant is provided in Civil Service Law and has two compulsory elements: institutional and functional. The institutional element states that a civil servant can be employed only in state institutions under direct and complete supervision of the Cabinet of Ministers (ministries and institutions subordinated to ministers or ministries, like the Public Procurement Office, the State Revenue Service, the Competition Council, the State Social Security Agency, etc.). There are no civil servants in other public institutions, like local municipalities or state universities. The functional criterion states that only those civil servants who carry out tasks related to administration of public funds, coordinate the activities of government policy, or draft legal enactments and other binding legal acts. ${ }^{17}$ If a person is employed in a state institution and does not fall under the functional criterion, then he is employed within ordinary labor relationships (accountants, desk officers, IT specialists, etc.).

The Latvian civil service can be characterized as a decentralized position system. Decentralization means that each state institution is responsible for management of its civil servants (recruitment, dismissal, etc.). The only institu-

14 Labor Law, adopted on 20.06.2001, English translation available at: https://likumi.lv/ta/en/ en/id/26019-labour-law (accessed: 1.07.2018).

15 Civil Procedure Law, adopted on 14.10.1998, English translation available at: https://likumi. $\mathrm{lv} / \mathrm{ta} / \mathrm{en} / \mathrm{en} / \mathrm{id} / 50500$-civil-procedure-law (accessed: 1.07.2018).

16 J. Briede, E. Danovskis, op. cit., p. 208.

17 See also ibid., p. 209. 
tion entrusted with the policy for the whole civil service is the State Chancellery. However, the State Chancellery is not entitled to supervise legality of decisions regarding civil servants in other state institutions. Previously (until 2008) there existed a special state institution - the Civil Service Authority - which was a functionally superior authority over all state institutions regarding matters of civil service. This institution was entitled to cancel illegal decisions made by other state institutions in civil service matters (for instance, illegal dismissals).

Position system means that there are no ranks of civil servants (except civil servants employed in the diplomatic and consular service) and theoretically the highest positions of the civil service can be filled by persons who have participated in an open competition and without prior experience in the civil service. ${ }^{18}$ Vacancies in the civil service can be filled either by an open competition or by a transfer of a civil servant to a vacant position. According to Civil Service Law, applicants are entitled to appeal against an unfavorable result. However, the Supreme Court has ruled that an applicant only has a "negative claim", that is, to ask for an annulment or declare an illegal decision to appoint a person in the civil service. Neither provisions of the Constitution, nor other provisions of law entitle an applicant to ask for his appointment to the position. ${ }^{19}$

Once a person becomes a civil servant, he is entitled to a permanent employment in the civil service, though he has no right to remain in the original position which was subject to competition. Theoretically he can be transferred to other civil service positions, even in other institutions without his acceptance momentarily after his appointment through a competition. Duties of a civil servant are listed in the job description (there are no contracts). A job description is an inner document and can be altered unilaterally by the head of the respective institution. A decision to transfer a civil servant from one position to another is usually treated as an internal matter and therefore it is outside judicial review. Transfer decisions are considered as administrative acts only when they significantly impair basic rights, including remuneration. ${ }^{20}$ Even if a civil servant is wrongfully dismissed and has successfully appealed against the respective decision, the court can restore him to a position "in the civil service", but not in the previous position. It is up to the institution to decide in which position, taking into account the skills, qualifications and the previous remuneration the civil servant can and should be restored. ${ }^{21}$ Unfortunately the law still lacks any guidelines on how institutions should handle the consequences of wrongful dismissal and reinstatement. Civil Service Law is

18 Ibid.

19 Judgment of the Department of Administrative Cases of the Supreme Court of 16.02.2015 in case no. 441/2015, point 10, http://www.at.gov.lv/downloadlawfile/4333 (accessed: 1.07.2018).

20 E. Danovskis, Tiesu prakse lietās par valsts dienestu. 2007-2016 [Summary of case law in public service cases. 2007-2016], pp. 13-15, http://www.at.gov.lv/files/uploads/files/6_Judikatura/ Tiesu_prakses_apkopojumi/2016/13-valsts\%20dienests-2016.doc (accessed: 1.07.2018).

${ }^{21}$ Ibid., p. 68. 
rather brief - it has fewer than 35 articles (originally 43 ) and regulates only the most important issues of civil service relationships. For instance, Article 41 of Civil Service Law provides grounds for termination of civil service relationships: death of a civil servant, bilateral agreement (usually when there are no other grounds for dismissal) and dismissal (12 grounds). One of the grounds for dismissal is "in connection with liquidation of the institution, or civil service staff reduction". Although the law does not provide any other provisions regarding these grounds for dismissal, during the aftermath of the so-called economic crisis of 2008-2009 the courts received many applications from civil servants who were dismissed on the grounds of this provision. As a result the courts deduced from the principle of equality several steps which should be followed when dismissing a civil servant due to staff reduction: 1) determining positions subject to reduction; 2) determining civil servants who are subject to comparison; 3 ) determining evaluation criteria for comparison; 4) performing a comparison in order to determine which civil servants have a right to remain in the civil service; 5) adopting the decision of dismissal. ${ }^{22}$ This example is intended to show that legal reality in the case of the Latvian civil service at times is more complex than provisions of the law. Some improvements and more detailed regulations of the civil service were intended by the Cabinet of Ministers who submitted a new draft law on the civil service to the parliament in 2014. The law provided more elaborate regulations on various practically important issues (for instance, term of dismissal) and contained a regulation that all persons employed in state institutions should be civil servants (employed in public legal relationships), including IT specialists, desk officers and other persons performing technical tasks. However, this law has not been adopted by parliament due to many objections by the labor unions.

\section{Development of state liability law}

Another area of Latvian administrative law that could be of interest for other researchers is the Latvian experience in the field of state liability. The concept of state liability is similar to the concept of civil liability for delicts and infringements of contractual obligations, except that state liability is caused by illegal actions carried out while exercising state powers, that is, actions performed in public legal relationships. The most developed part of state liability law is liability of the state caused by illegal administrative acts and physical actions.

The basic legal question in this area is: if and when is a private person (both natural and legal person) entitled to a supplementary claim of written apology or monetary compensation in addition to a basic claim (a claim to annul the ad-

22 Ibid., pp. 35-48. 
ministrative act or declare it illegal or a claim to issue a favorable administrative act)? Administrative Procedure Law regulated this issue since 2001 in a rather general manner, stipulating that a private person is entitled to receive effective remedy for personal harm, moral harm and losses (material harm). In 2005 the Law on Compensation of Damage Caused by State Administration Institutions ${ }^{23}$ was adopted, regulating in detail both material preconditions and the procedure of compensation for damages caused by illegal administrative acts and physical action. The law contained definitions of "losses", "personal harm" and "moral harm". The definition of "losses" is the same as in civil law and contains both existing loss (damnum emergens) and anticipated profits (lucrum cessans). "Personal harm" was defined as harm to a natural person's life, physical integrity, health, freedom, dignity and respect, personal, family or commercial secrets and other non-material rights and legally protected interests. A legal person was also entitled to compensation for personal harm done to his or her business reputation, commercial secrets and other non-material rights and legally protected interests. ${ }^{24}$ "Moral harm" was defined as "suffering caused to a natural person by a significant infringement of his or her rights or legally protected interests". ${ }^{25}$ Part Three of Article 11 of the mentioned law also provided that "legal grounds for compensation of a moral harm are proven if an infringement of rights or legally protected interests of a natural person is proven". At one point courts used to conclude that moral harm is caused every time when an authority has issued an illegal administrative act. In other words - every administrative act creates moral harm. For instance, in a case where a prison authority failed to provide a female officer with a female uniform (the law provided different uniforms for men and women, and only male uniforms were available at the time), the court concluded that moral harm is done, though it can be properly compensated by a written apology. ${ }^{26}$ Other typical examples where "moral harm" was proven was failure to timely reply to a submission by a person, to timely issue an administrative act, etc. ${ }^{27}$ Sometimes courts failed to notice the idea behind "moral harm" - it was not to compensate "moral sufferings" but to provide an opportunity to grant effective remedy where

23 Valsts pārvaldes iestāžu nodarīto zaudējumu atlīdzināšanas likums, adopted on 2.06.2005, https://likumi.lv/doc.php?id=110746 (accessed: 1.07.2018).

24 Article 8 of the Law on Compensation of Damage Caused by State Administration Institutions in force until 28 February 2018.

25 Article 9 of the Law on Compensation of Damage Caused by State Administration Institutions in force until 28 February 2018.

26 Judgment of the Administrative Regional Court of 1.09.2009 in case no. AA43-2183-09/8, https://manas.tiesas.lv/eTiesasMvc/nolemumi/pdf/14857.pdf (accessed: 1.07.2018).

27 E. Danovskis, Morālā kaitējuma atlīdzināšsana administratīvajās lietās. Tiesu prakses apkopojums [Compensation of moral harm in administrative cases. Summary of case law] Riga 2011, http://www.at.gov.lv/files/uploads/files/6_Judikatura/Tiesu_prakses_apkopojumi/2016/6-morala_kaitejuma_atlidzinasana-2011.doc (accessed: 1.07.2018),pp. 41-42. 
basic remedies (for instance, annulment of the administrative act) seems insufficient in comparison with the infringement.

In 2018 "personal harm" and "moral harm" were merged into a concept of "non-material" or "non-pecuniary" harm. At present "non-pecuniary" harm is defined as an infringement of a natural or legal person's non-material rights or legally protected interests creating unfavorable non-material consequences. Unfavorable non-material consequences are understood as objectively determinable facts. For instance, if a person has applied for a new passport and has received an illegal denial, non-material consequences can be a lost opportunity for travel (if it is proven that such travel was planned). If the infringement per se is significant (for instance, illegal forceful hospitalization in a psychiatric hospital), then the non-material harm shall be presumed (Part Three, Article 11 of the Law on Compensation of Damage Caused by State Administration Institutions). Such a regulation is intended to ensure the principle of effective legal remedy. In some instances annulment of an administrative act will be considered as an effective remedy. However, there are several instances where annulment is not an effective remedy and such remedies as a written apology or monetary compensation should be applied. In determining whether a legal remedy is effective, the courts are obliged to take into account functions of effective remedies. The constitutional court has ruled that right to effective remedy contained in the third sentence of Article 92 of the Constitution "fulfils several functions. First of all, this is compensatory function, conciliation function, as well as general and special prevention function. The purpose of the above mentioned functions is to ensure effective restoration of justice and protection of fundamental rights because only such compensation that is also considered as legal remedy shall comply with the third sentence of Article 92 of the Constitution". 28

\section{Development of administrative offence law}

A special and very important branch of administrative law is administrative offence law. In order to carry out tasks of law enforcement (executive power), a power to impose administrative fines has been granted to various administrative institutions. In Latvia there are two types of administrative offences. The largest part of administrative offences are those which are provided in the Code of Administrative Offences and bylaws of local municipalities. The respective fines are applied within a procedure prescribed in the Code of Administrative Offences and the decisions can be appealed in ordinary courts (they are not administrative acts).

28 Judgment of the Constitutional Court of the Republic of Latvia of 6.06.2012 in case no. 2011-21-01, point 11.1, http://www.satv.tiesa.gov.lv/web/viewer.html?file=http://www.satv.tiesa.gov. lv/wp-content/uploads/2011/12/2011-21-01_Spriedums_ENG.pdf\#search= (accessed: 1.07.2018). 
The second part of administrative offences is offences scattered in around 20 laws, for instance, Competition $\mathrm{Law}^{29}$, Credit Institution Law, ${ }^{30}$ etc. The respective fines are imposed by administrative acts which can be appealed in administrative courts. This dichotomy of administrative fines has various historical reasons. ${ }^{31}$

The Code of Administrative Offences was adopted in 1984 within the framework of the Soviet legal reform in administrative offences. The law is still in force, although it has been amended more than 130 times and there have been several attempts to draft new law. The Code provides that the subjects of administrative offences are physical persons and legal entities. Legal entities are the subjects of administrative offences only if it is clearly provided in the sanction of the respective offence. Only private legal entities are the subjects of administrative offences public legal entities and their institutions cannot be punished. Instead, the managers of public legal entities and their institutions are to be punished for the illegal activities of public legal entities. ${ }^{32}$ It is a very important principle, because it would be absurd to allow a situation where one state institution could impose fines on another institution.

It is expected that in 2018 the parliament will adopt the Administrative Offences Procedure Law which repeals the Code of Administrative Offences. The draft law provides several important changes. First of all, it abandons the old concept of fault being understood as intent and negligence, that is, mental attitude. Instead a new concept of "culpability" is introduced - it means that once a person has committed activity of inactivity corresponding to a provision prescribing administrative liability, this person is subject to an administrative fine unless he proves objective circumstances that preclude administrative liability (insanity, force majeure, etc.).

Perhaps the most notable change is so called "decodification" of administrative offences. The present Code of Administrative Offences lists all administrative offences in the "Special Part" of the Code. The draft law provides only general provisions on all administrative offences and procedure for their adoption and judicial review. This means that administrative offences would be listed not in one law, but in each law's regulatory subject matter (for instance, administrative liability breaches of consumer protection provisions would be provided in the respective law regulating consumer protection) ${ }^{33}$ It is expected that with the adoption of the new law, administrative offence law will develop more rapidly.

29 Competition Law, adopted on 4.10.2001, English translation available at: https://likumi.lv/ ta/en/en/id/54890-competition-law (accessed: 1.07.2018).

30 Credit Institution Law, adopted on 5.10.1995, English translation available at: https://likumi.lv/ta/en/en/id/37426-credit-institution-law (accessed: 1.07.2018).

31 See E. Danovskis, "Significance of principles of penal law in administrative law", Journal of the University of Latvia "Law" 2017, no. 10, https://www.lu.lv/fileadmin/user_upload/lu_portal/ apgads/PDF/Book_Jur_Zin_10-internetam.pdf (accessed: 1.07.2018), pp. 200-217.

32 J. Briede, E. Danovskis, op. cit., p. 216.

33 Ibid., pp. 216-217. 


\section{Bibliography}

Bogdandy A. von, Huber P.M., Cassese S., eds., The Administrative State, The Max Planck Handbooks in European Public Law, vol. 1, Oxford 2017.

Briede J., Danovskis E., "Administrative law and procedure", [in:] The Law of the Baltic States, eds. T. Kerikmäe, K. Joamets, J. Pleps, A. Rodina, T. Berkmanas, E. Gruodyte, Cham 2017.

Danovskis E., "Establishment of the civil service in Latvia after the proclamation of the state (19181920)", Journal of the University of Latvia "Law" 2014, no. 7, https://www.journaloftheuniversityoflatvialaw.lu.lv/fileadmin/user_upload/lu_portal/projekti/journaloftheuniversityoflatvialaw/No7/8.Edvins_Danovskis.pdf (accessed: 1.07.2018).

Danovskis E., Morālā kaitējuma atlīdzināšana administratīvajās lietās. Tiesu prakses apkopojums, Rīga 2011, http://www.at.gov.lv/files/uploads/files/6_Judikatura/Tiesu_prakses_ apkopojumi/2016/6-morala_kaitejuma_atlidzinasana-2011.doc (accessed: 1.07.2018).

Danovskis E., "Significance of principles of penal law in administrative law", Journal of the University of Latvia “Law" 2017, no. 10, https://www.lu.lv/fileadmin/user_upload/lu_portal/apgads/PDF/Book_Jur_Zin_10-internetam.pdf (accessed: 1.07.2018).

Danovskis E., Tiesu prakse lietās par valsts dienestu. 2007-2016, Rīga 2016, http://www.at.gov. lv/files/uploads/files/6_Judikatura/Tiesu_prakses_apkopojumi/2016/13-valsts\%20dienests-2016.doc (accessed: 1.07.2018).

Fromont M., "A typology of administrative law in Europe", [in:] The Administrative State, eds. A. von Bogdandy, P.M. Huber, S. Cassese, The Max Planck Handbooks in European Public Law, vol. 1, Oxford 2017.

Handbuch Ius Publicum Europaeum, vols. 1-6, Heidelberg 2007-2016.

\section{Legal sources}

Civil Procedure Law, adopted on 14.10.1998, https://ikumi.lv/ta/en/en/id/50500-civil-procedurelaw (accessed: 1.07.2018).

Administrative Procedure Law, adopted on 25.10.2001, https://likumi.lv/ta/en/en/id/55567-administrative-procedure-law (accessed: 1.07.2018).

Competition Law, adopted on 4.10.2001, https://likumi.lv/ta/en/en/id/54890-competition-law (accessed: 1.07.2018).

Credit Institution Law, adopted on 5.10.1995, https://ikumi.lv/ta/en/en/id/37426-credit-institution-law (accessed: 1.07.2018).

Judgment of the Administrative Regional Court of 1.09.2009 in case no. AA43-2183-09/8, https:// manas.tiesas.lv/eTiesasMvc/nolemumi/pdf/14857.pdf (accessed: 1.07.2018).

Judgment of the Constitutional Court of the Republic of Latvia of 6.06.2012. in case no. 2011-2101, http://www.satv.tiesa.gov.lv/web/viewer.html?file=http://www.satv.tiesa.gov.lv/wp-content/uploads/2011/12/2011-21-01_Spriedums_ENG.pdf\#search= (accessed: 1.07.2018).

Judgment of the Department of Administrative Cases of the Supreme Court of 16.02.2015 in case no. 441/2015, http://www.at.gov.lv/downloadlawfile/4333 (accessed: 1.07.2018).

Judgment of the Supreme Court of 22.09.2017 in case no. 767/2017, https://manas.tiesas.lv/eTiesasM$\mathrm{vc} /$ nolemumi/pdf/328468.pdf (accessed: 1.07.2018).

Labor Law, adopted on 20.06.2001, https://ikumi.lv/ta/en/en/id/26019-labour-law (accessed: 1.07.2018).

State Civil Service Law, adopted on 7.09.2000, https://likumi.lv/ta/en/en/id/10944-state-civil-service-law (accessed: 1.07.2018). 